Article

\title{
Variable Interest Entity, Offshore Domesticated Foreign Finance, and the Political Economy of China's Internet Firms: The Case of Alibaba
}

\author{
Can Zhao
}

Citation: Zhao, Can. 2022. Variable Interest Entity, Offshore

Domesticated Foreign Finance, and the Political Economy of China's Internet Firms: The Case of Alibaba Social Sciences 11: 99. https:// doi.org/10.3390/socsci11030099

Academic Editors: Guoguang Wu and Nigel Parton

Received: 15 January 2022

Accepted: 21 February 2022

Published: 24 February 2022

Publisher's Note: MDPI stays neutral with regard to jurisdictional claims in published maps and institutional affiliations.

Copyright: (C) 2022 by the author. Licensee MDPI, Basel, Switzerland. This article is an open access article distributed under the terms and conditions of the Creative Commons Attribution (CC BY) license (https:// creativecommons.org/licenses/by/ $4.0 /$ )
Department of Political Science, University of Victoria, Victoria, BC V8P 5C2, Canada; zhaocan@uvic.ca

\begin{abstract}
This article aims to show how the globalized securities market in general and a transnational legal business structure named variable interest entity (VIE) in particular has challenged our conventional understanding of "foreignness" as a geographical concept in cross-border capital flow and ushers in a new type of foreign investment which I call "offshore domesticated foreign finance" (ODFF). By performing a case study on Alibaba—one of the world's leading VIE-structured Internet companies-and mapping out the company's fund-raising history and personnel appointment mechanism with the help of company releases and news reports, this article shows how ODFF makes a company de jure foreign-incorporated and -owned but de facto China-based and Chinese-controlled. This article also demonstrates that ODFF's primary function is to allow China-based Internet firms to tap into international financial markets while helping Chinese entrepreneurs and managers-despite their minority shareholdings-to control the company. These findings shed light on how financial globalization has transformed the cross-border capital movement and corporate governance.
\end{abstract}

Keywords: globalization; capitalism; internet company; cross-border capital flow; foreign investment; corporate finance; corporate governance; Alibaba; variable interest entity (VIE)

\section{Introduction}

19 September 2014 marked an iconic moment in the history of capitalism. Alibaba Group, a conglomerate specializing in various Internet-related businesses such as ecommerce, cloud computing, and electronic payments, hit a record USD 25 billion through its initial public offering (IPO) on the New York Stock Exchange (NYSE) - the largest ever proceeding in the history of the stock market. ${ }^{1}$ The massive amount of funding that Alibaba had managed to raise, as well as its successful debut in the international stock market, gained the company lavish limelight in both Chinese and international media coverage. Xinhua (2014), China's state-owned news outlet and the Chinese Communist Party's (CCP) mouthpiece, dedicated a special report that spared no praise by dubbing Alibaba as "a 'Chinese Miracle' on Wall Street". The CCP Hangzhou Municipal Committee, based in the same city as Alibaba's headquarters, sent out a letter of congratulations to the corporate giant, calling it "the golden business card of the city and the pride of every citizen" (China National Radio 2014).

However, perhaps to the great surprise of many, the Alibaba Corporation, the company listed in the NYSE, was not even a Chinese company in the legal sense. It was domiciled in the Cayman Islands and thus was governed by the Caribbean island-state's Articles of Association and Companies Law. Furthermore, Softbank, a Japanese conglomerate, and Yahoo, an American web service provider, along with many other Western institutional and financial investors held more than half of Alibaba's shares for years both before and after the company's extravagant IPO on the NYSE. In contrast, Alibaba's Chinese co-founders and managers, three dozen in total, aggregately held the minority of its issued shares, owning only $14.6 \%$ of them at the time of the 2014 IPO (Securities and Exchange Commission 2014). Even more perplexingly, foreign investment is forbidden in China's Internet sector. In fact, 
over the years, Chinese regulators have reiterated the importance of Internet security, and have consistently upgraded the Internet sector's blacklist against foreign capital due to the sector's political sensitivity (Office of the Central Cyberspace Affairs Commission of China 2018). So why did the Chinese authorities and media openly claim Alibaba as a Chinese company despite it being foreign-incorporated and -owned?

By investigating Alibaba's fundraising history and decision-making mechanism, I argue that the company's corporate structure represents a new type of cross-border capital movement which I call offshore domesticated foreign finance (ODFF). ODFF allows Chinabased Internet firms to fundraise from international financial markets and retain corporate control despite minority shareholding. More specifically, thanks to the globalization of financial markets, firms based in Mainland China can camouflage as foreign entities by creating special purpose vehicles (SPVs) in offshore financial centers (OFCs). Because of their historical and legal affinities with the major financial regulations of the Global North, SPVs, despite primarily existing on paper, are legally recognized as companies in the Global North and are thus able to raise funds from financial markets in the developed world. Ostensibly and legally speaking, SPVs are owned and controlled by outside China investors for two reasons. One is that the global investors possess more than $10 \%$ of the SPVs' issued shares. ${ }^{2}$ The other is that cross-border capital flow into China takes a form that allows SPVs to establish local affiliations inside of China. However, the de facto power dynamics between the SPVs and their global investors is the opposite. The reason why Alibaba, an Internet company mainly and nominally owned by foreign investors could bypass Beijing's foreign investment prohibition was not because of regulatory negligence, but rather because the company was Chinese-controlled.

Arguably, ODFF challenges our conventional understanding of "foreignness" as related to cross-border capital flow. As Figure 1 below demonstrates, conventionally, the term "foreign" only designates that the residence of the investor is geographically different from the residence of the receiving corporate entity. However, ODFF demonstrates that "foreignness" is a malleable concept. ${ }^{3}$ In a geographical sense, the fund-absorbing SPVs are concomitantly foreign investment recipients and initiators. When the real cross-border capital flow into China takes place, it is an intra-firm financial allocation since the financial proceedings are already "domesticated" under Chinese corporate control.

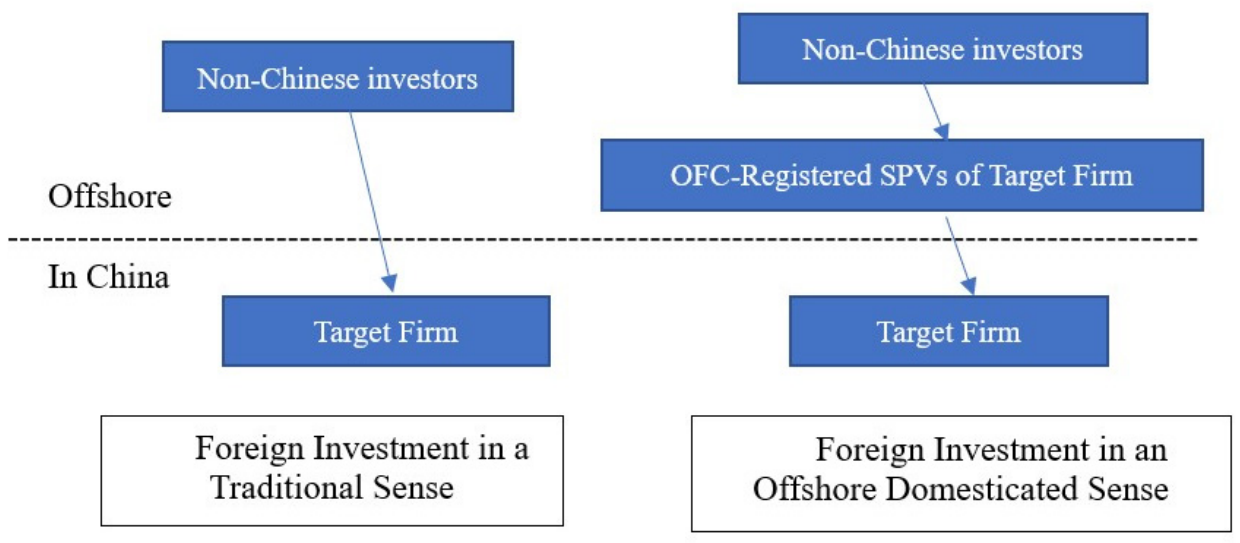

Figure 1. Traditional and Transformed Understandings of Foreign Capital Inflow. Source: The Author's Conceptualization.

To shed light upon the foreign-financed and Chinese-controlled characteristics of Alibaba, this project benefits from two types of research data. One refers to the company filings or disclosures that Alibaba regularly released to investors or submitted to security and exchange regulators from where they were listed, among which its prospectuses for IPOs and annual reports are particularly useful. The other refers to Chinese business and financial news outlets, such as Caijing, Caixin, and 21Shiji Jingji Baodao, which offer well-informed, in-depth, and high-caliber analyses. These resources are thus referenced 
and triangulated with news reports from their international counterparts such as Financial Times, Bloomberg, and The Wall Street Journal. Methodologically, this study uses process tracing (Collier 2011) to examine the historical evolution of two types of institutions inside a firm's governance, namely corporate finance and decision making.

Extant literature on VIE and Chinese Internet companies has underscored the risks this legally ambiguous corporate structure presents for foreign investors (Gillis and Lowry 2014; Ma 2013a; Shi 2013; Rosier 2014). Accordingly, many have advocated for more regulatory oversight (Johnson 2014; Bain 2021). I do not dismiss any of these findings as unimportant or invalid. Rather, this paper argues that for Chinese Internet entrepreneurs, VIE represents a desirable corporate design that allows them to parlay globally raised finance and retain corporate control.

The remainder of this article proceeds as follows. Section 2 presents the general features of the ODFF absorption structure that Alibaba uses called Variable Interest Entity (VIE). Highlighting the globally-funded nature of the company, Section 3 will start with a survey of the company's fund acquisition history that involved multiple rounds of equitybased investment injected from global investors via its Cayman Islands-domiciled shell company from the company's establishment in 1999 until the most recent secondary IPO in Hong Kong Securities Exchanges (HKSE) in 2019. Then, by investigating its unique corporate decision-making mechanism named the Lakeside Partnership (Hupan Hehuoren), Section 4 shows how Alibaba is Chinese controlled. In Section 5, the Alipay incident in 2011 will be discussed as a corroboration of the research finding that VIE benefited the Chinese minority shareholding entrepreneurs yet harmed foreign owners' interests. Concluding remarks are offered in Section 6.

\section{C'est la "VIE": General Features of Variable Interest Entity}

VIE was originally an account standard used for corporate financing. The term first appeared in the 2003 interpretation given by the U.S. Financial Accounting Standards Boardin response to the Enron scandal, which aimed to confirm that if one entity had controlling financial interest over the other, then the financial statements should be merged, regardless of whether the control was exercised in majority voting, and the controlled company was considered as the controller's VIE (Financial Accounting Standards Board 2008). This accounting concept has been widely used by China-based Internet companies to "dress up" their corporate governance structure and acquire ODFF from global financial markets.

As Figure 2 shows, Chinese entrepreneurs and founders of Internet companies would build a VIE structure by first registering a parent holding company (HoCo) in an OFC. Many OFCs are archipelago states in the Caribbean region, with the Cayman Islands being a particularly popular destination, not only because of its tax-free status, but because its common legal framework and recognition by international investors facilitates the HoCo's later IPO on major securities exchanges of the Global North generally, and in the U.S. and Hong Kong particularly. As the fundraising vehicle, the HoCo would draw global financial investments, usually starting with several rounds of venture capital or private equity investments before seeking public investment after initiating an IPO. This HoCo existed mainly on paper and would "establish" a wholly foreign-owned enterprise inside China, sometimes through an additional intermediary registered in Hong Kong to take advantage of favorable policies granted by Beijing to Hong Kong-registered investment. ${ }^{4}$ However, these wholly foreign-owned enterprises do not directly operate in China-based Internet assets and businesses because the Chinese regime prohibits foreign ownership in this sector. To get around this, these wholly foreign-owned enterprises would provide funding, technology, and managerial expertise through commercial contracts, instead of direct equity ownership to real operating companies managing Internet assets in China owned and controlled by the very Chinese entrepreneurs who created the HoCo offshore. Under such construction, the operating company would become a VIE whose financial statements were merged with those of the wholly foreign-owned enterprise and the HoCo, 
thus being legally considered an affiliation of the listed company by security regulators from the listed destination in the Global North. In reality, however, a VIE allowed Chinese founders and managers to wield de facto control and management of China-based Internet assets and businesses despite the de jure majority ownership of foreign investors.

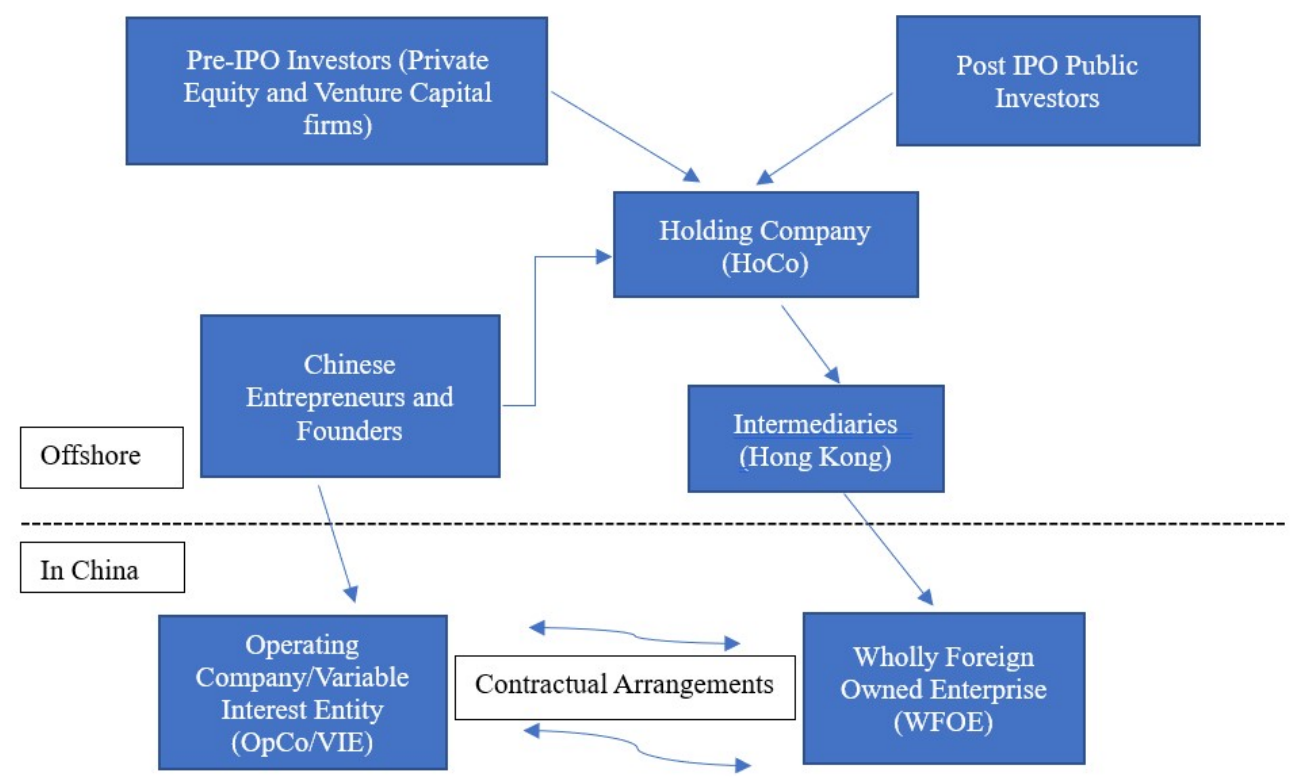

Figure 2. Conceptual Organizational Chart of the VIE Structure. Sources: The Author's Composition Based on (Gills 2011) and (Securities and Exchange Commission 2014).

So what contracts are needed to establish this indirect non-equity relationship between the wholly foreign-owned enterprise and the operating company and to bundle them as one company in an accounting and legal sense? Generally speaking, despite case-by-case variations, the contractual arrangements typically require five essential elements. The first is a technical cooperation agreement that makes the wholly foreign-owned enterprise both the provider of services, technologies, and intellectual property rights to the operating company and the recipient of the operating company's revenue and profits in the form of service or franchise fees. The economic gains are then repatriated to the offshore-established HoCo, which holds investments from outside China. Secondly, a loan agreement allows the operating company to borrow interest-free funds from the wholly foreign-owned enterprise that would be used exclusively for capital accumulation by the operating company. Third, a voting proxy will be signed, granting the HoCo and its offshore affiliates the rights to directly involve themselves in the board's decision-making and to send board members to the operating company. Fourth, an equity pledge agreement then grants the wholly foreignowned enterprise first-priority security interests in all shares owned by the operating company's shareholders, serving as a collateral for the proper performance of contractual arrangements. ${ }^{5}$ Last but not least, a call option agreement promises that, on the condition that the Chinese authorities allow non-Chinese direct ownership in the information services sector, the HoCo will be allowed to acquire the equity interests and assets of the operating company at a pre-negotiated price.

On paper, the OFC-domiciled parent HoCo, in the capacity of a foreign investor, would establish a wholly foreign-owned enterprise inside China and maintain corporate control over the operating company through multiple contracts. As the VIE of the wholly foreign-owned enterprise, this operating company would be considered an affiliation of the HoCo in accounting and legal matters. In reality, however, the power dynamic that plays out between the operating company inside China and the HoCo owned by foreign investors is quite the opposite. Although foreign investors own the offshore-domiciled HoCo through the majority equity shares they hold, their influence on assets inside China 
is seriously limited because they do not wield effective control over the entity that operates assets. ${ }^{6}$ In practice, the wholly foreign-owned enterprise and the operating company are a single institution with two names controlled by the same group of Chinese entrepreneurs and company founders. Their company names, office locations, and the composition of board members and chief executives overlap and may even be the exact same (Ding and Sun 2011). In other words, even though the wholly foreign-owned enterprise is legally and geographically a completely foreign-invested company, it is de facto owned and controlled by the Chinese entrepreneurs and managers that set up the entire complex structure. Through the proxy voting agreements signed between the wholly foreign-owned enterprise and the operating company, the offshore HoCo delegates its voting power to Chinese entrepreneurs for the daily operation and management of businesses inside China on their behalf.

As Table 1 shows, VIE has helped dozens of Chinese Internet companies to fundraise from the American and Hong Kong securities markets. As of October 2020, 51 of the 217 China-based and Chinese-controlled companies listed on U.S. exchanges operated in the Internet sector, together bringing home USD 35.631 million. ${ }^{7}$ Because of Beijing's restrictions against foreign corporate control in this sector, all of them used the VIE structure. ${ }^{8}$

Table 1. Top 21 VIE-structured Chinese Internet Companies that Trade on U.S. and Hong Kong Stock Exchanges with an IPO Value Surpassing USD 100 million before October 2020.

\begin{tabular}{|c|c|c|c|c|c|}
\hline Company & $\begin{array}{l}\text { IPO Value } \\
\text { USD Million }\end{array}$ & IPO Time & Primary Service(s) & Listed Exchange & Lead Underwriters \\
\hline \multirow{3}{*}{ Alibaba * } & 1700 & November 2007 & B2B E-Commerce & HKSE & $\begin{array}{l}\text { Goldman Sachs, } \\
\text { Morgan Stanley, } \\
\text { Deutsche Bank }\end{array}$ \\
\hline & 21,767 & September 2014 & $\begin{array}{l}\text { E-Commerce, } \\
\text { Third Party } \\
\text { Payment }\end{array}$ & NYSE & $\begin{array}{l}\text { Credit Suisse, } \\
\text { Deutsche Bank, } \\
\text { Goldman Sachs, JP } \\
\text { Morgan Chase, } \\
\text { Morgan Stanley, } \\
\text { Citigroup }\end{array}$ \\
\hline & 13,000 & November 2019 & $\begin{array}{l}\text { E-Commerce, } \\
\text { Cloud Computing, } \\
\text { Digital Media and } \\
\text { Entertainment }\end{array}$ & HKSE & $\begin{array}{c}\text { CICC, Credit Suisse, } \\
\text { Citi Group, J.P. } \\
\text { Morgan, Morgan } \\
\text { Stanley }\end{array}$ \\
\hline iQiYi & 2250 & March 2018 & Online Video & NASDAQ & $\begin{array}{c}\text { Goldman Sachs, } \\
\text { Merrill Lynch, Credit } \\
\text { Suisse }\end{array}$ \\
\hline JD.com & 1800 & March 2014 & E-Commerce & NASDAQ & Merrill Lynch, UBS \\
\hline Pinduoduo & 1626 & August 2018 & E-Commerce & NASDAQ & $\begin{array}{c}\text { CICC, Credit Suisse, } \\
\text { Deutsche Bank }\end{array}$ \\
\hline Tencent Music & 1100 & December 2018 & Online Music & NYSE & $\begin{array}{c}\text { Bank of America, } \\
\text { Deutsche Bank, } \\
\text { Goldman Sachs, JP } \\
\text { Morgan, Morgan } \\
\text { Stanley }\end{array}$ \\
\hline Douyu & 775 & July 2019 & $\begin{array}{c}\text { Video } \\
\text { Livestreaming }\end{array}$ & NASDAQ & $\begin{array}{l}\text { Morgan Stanley, JP } \\
\text { Morgan, Bank of } \\
\text { America, Merrill } \\
\text { Lynch, CMB } \\
\text { International }\end{array}$ \\
\hline
\end{tabular}


Table 1. Cont.

\begin{tabular}{|c|c|c|c|c|c|}
\hline Company & $\begin{array}{l}\text { IPO Value } \\
\text { USD Million }\end{array}$ & IPO Time & Primary Service(s) & Listed Exchange & Lead Underwriters \\
\hline Renren & 743 & May 2011 & Social Networking & NYSE & $\begin{array}{l}\text { Merrical Lynch, } \\
\text { Deutsche Bank, } \\
\text { Morgan Stanley }\end{array}$ \\
\hline Sougou.com & 585 & November 2017 & Internet Search & NYSE & $\begin{array}{l}\text { JP Morgan, Credit } \\
\text { Suisse, Goldman } \\
\text { Sachs, CICC }\end{array}$ \\
\hline ChinData & 540 & September 2020 & Data Center & NASDAQ & $\begin{array}{l}\text { Morgan Stanley, } \\
\text { CitiGroup }\end{array}$ \\
\hline Kingsoft Cloud & 510 & May 2020 & Cloud Service & NASDAQ & $\begin{array}{l}\text { JPMorgan, UBS, Credit } \\
\text { Suisse, CICC }\end{array}$ \\
\hline Bilibili & 483 & March 2018 & Online Video & NASDAQ & $\begin{array}{l}\text { Merrill Lynch, JP } \\
\text { Morgan Chase, } \\
\text { Morgan Stanley }\end{array}$ \\
\hline Dada Nexus & 320 & June 2020 & $\begin{array}{l}\text { Online Retail and } \\
\text { Delivery }\end{array}$ & NASDAQ & $\begin{array}{c}\text { Goldman Sachs, Bank } \\
\text { of America, Jefferies }\end{array}$ \\
\hline One Connect & 312 & December 2019 & Financial Data & NYSE & $\begin{array}{l}\text { Morgan Stanley, } \\
\text { Goldman Sachs, J.P. } \\
\text { Morgan, Ping An }\end{array}$ \\
\hline Weibo & 286 & March 2018 & Microblog & NASDAQ & $\begin{array}{l}\text { Credit Suisse, } \\
\text { Goldman Sachs }\end{array}$ \\
\hline Momo & 216 & December 2014 & Instant Messaging & NASDAQ & $\begin{array}{c}\text { Morgan Stanley, Credit } \\
\text { Suisse, J.P. Morgan, } \\
\text { China Renaissance } \\
\text { Securities }\end{array}$ \\
\hline Tencent & 200 & June 2004 & Instant Messaging & HKSE & Goldman Sachs \\
\hline 21 Vianet & 195 & April 2011 & $\begin{array}{l}\text { Internet Data } \\
\text { Center }\end{array}$ & NASDAQ & $\begin{array}{c}\text { Deutsche Bank, } \\
\text { Goldman Sachs, } \\
\text { Barclays }\end{array}$ \\
\hline GDS Holdings & 193 & November 2016 & $\begin{array}{l}\text { Internet Data } \\
\text { Center }\end{array}$ & NASDAQ & $\begin{array}{l}\text { Credit Suisse, JP } \\
\text { Morgan }\end{array}$ \\
\hline Huya & 180 & May 2018 & $\begin{array}{c}\text { Game } \\
\text { Livestreaming }\end{array}$ & NYSE & $\begin{array}{c}\text { Credit Suisse, } \\
\text { Goldman Sachs, } \\
\text { CitiGroup, Jefferies }\end{array}$ \\
\hline Cheetah Mobile & 168 & May 2014 & $\begin{array}{l}\text { Mobile Phone } \\
\text { Application }\end{array}$ & NYSE & $\begin{array}{l}\text { Morgan Stanley, JP } \\
\text { Morgan, Credit Suisse }\end{array}$ \\
\hline Autohome & 133 & May 2013 & $\begin{array}{l}\text { Automobile } \\
\text { Information }\end{array}$ & NYSE & $\begin{array}{l}\text { Deutsche Bank, } \\
\text { Goldman Sachs, }\end{array}$ \\
\hline Yunji & 121 & May 2019 & E-Commerce & NASDAQ & $\begin{array}{c}\text { Morgan Stanley, Credit } \\
\text { Suisse, JP Morgan, } \\
\text { CICC }\end{array}$ \\
\hline Baidu & 109 & August 2005 & Internet Search & NASDAQ & $\begin{array}{l}\text { Goldman Sachs, Piper } \\
\text { Jaffray, Credit Suisse }\end{array}$ \\
\hline
\end{tabular}

* Alibaba delisted the B2B branch in 2012. Source: U.S.-China Economic and Security Review Commission (2021) Alibaba (2007); Market Watch (2004); Hong Kong Stock Exchange (2019).

Alibaba represents one of the largest and most successful Internet companies in China. As the table above shows, about $61 \%$ of the total proceedings from Chinese Internet companies in American stock markets between 2000 and 2020 came from Alibaba alone. In 2013, the year before Alibaba's NYSE IPO, Alibaba alone occupied $84 \%$ of China's ecommerce market share, and transactions worth USD 248 billion took place on e-commerce 
platforms operated by the company (Cui 2014). The sections below investigate how this giant became globally funded while still being under Chinese control.

\section{Channeling in ODFF via VIE: Alibaba's Nine Rounds of Fund Acquisition}

As Table 2 shows, Alibaba has benefited from nine rounds of ODFF boosting. Ma Yun and eighteen others at his residential apartment at Lakeside (Hupan) Garden in Hangzhou founded Alibaba in February 1999 with an initial aggregate investment of RMB 500 thousand (around USD 60 thousand) that came from their personal savings. Ma immediately embarked on a fundraising trip to the U.S., meeting venture capital and private equity investors, but as he later revealed, "nobody was interested in Alibaba, and I was denied one by one" (Su 2014). However, an opportunity came in May 1999, when Ma was introduced to Joseph Tsai, a Taiwanese-Canadian employee of the Swedish investment company Investor $\mathrm{AB}$ who was impressed by Ma's business plan and ambition to create an online marketplace for international trade. Tsai quit his position at Investor $\mathrm{AB}$, where he earned an annual salary of USD 700 thousand per year, and joined Alibaba as the only co-founder with a western education background and expertise in international banking and investment, despite being paid barely RMB 6 thousand (around USD 725) a year (Flannery 2014; Zhang 2019). By serving as Alibaba's chief financial officer (CFO) and chief operating officer (COO), Tsai quickly tapped into his professional networks and convinced four institutional investors, including world-renowned investment bank Goldman Sachs and his former employer Investor AB, to invest USD 5 million into Alibaba through its OFC-registered SPV (Flannery 2014; Zhang 2019). With this initial round of foreign investment, Ma and his associates moved the company from their residential apartment to a commercial building. A year later, during a trip to China to seek potential investment opportunities, Masayoshi Son, Founder and Chief Executive Officer (CEO) of the Japanese conglomerate Softbank, which owned one of the world's largest Internet- and technology-focused venture capital funds, was persuaded by Ma to support his endeavors. As a result, Softbank convinced five other institutional investors to put USD 25 million into Alibaba, with Softbank giving the majority share of USD 20 million (Flannery 2014; Zhang 2019).

Table 2. Nine Rounds of Alibaba's Equity-based Fundraising from Financial Markets outside China.

\begin{tabular}{|c|c|c|c|}
\hline $\begin{array}{l}\text { Round of Financial } \\
\text { Acquisition }\end{array}$ & Time & Fund Raised USD Million & Major Global Investors \\
\hline 1 st & 1999 & 5 & $\begin{array}{l}\text { Goldman Sachs, Fidelity Capital, Technology } \\
\text { Development Fund of Singapore, Investor AB }\end{array}$ \\
\hline 2nd & 2000 & $25 *$ & Softbank, Fidelity Capital, Transpac Capital \\
\hline $3 r d$ & 2004 & $82 * *$ & $\begin{array}{c}\text { Soft Bank, Fidelity Capital, Granite Global } \\
\text { Ventures, Venture TDF China }\end{array}$ \\
\hline 4th & 2005 & $1000^{* * *}$ & Yahoo \\
\hline 5 th & 2007 & $1700 * * * *$ & IPO on HKSE \\
\hline 6 th & 2011 & 2000 & Silver Lake, DST Capital, Temasek, YF Capital \\
\hline 7th & 2012 & 4300 & $\begin{array}{c}\text { Silver Lake, DST Capital, Temasek, YF Capital, } \\
\text { Boyu Capital, China Investment Corporation, } \\
\text { China International Trust Investment } \\
\text { Corporation (CITIC), China Development Bank }\end{array}$ \\
\hline 8th & 2014 & 21,767 & IPO on NYSE \\
\hline 9th & 2019 & 13,000 & Secondary IPO on HKSE \\
\hline
\end{tabular}

${ }^{*}$ of which USD 20 million came from Softbank. ${ }^{* *}$ of which USD 60 million came from Softbank. ${ }^{* * *}$ USD 1 billion cash plus all of Yahoo's assets inside China. ${ }^{* * * *}$ A total of USD 274 million in proceedings, with a 24-month lock-up period, came from eight cornerstone investors, including Yahoo, AIG Global Investment Corporation, Foxconn (Far East), China Industrial Bank Corporation (Asia), Cisco Systems International, Baldonna Investments, Finawood Investments, and Honeybush. The listing was withdrawn in June 2012. Source: Lin (2009, p. 337); Alibaba (2004, 2005, 2007, 2012b); Securities and Exchange Commission (2014); Hong Kong Stock Exchange (2019).

Feeling increasingly optimistic about China's e-commerce market, Softbank mustered a group of Internet-focused venture capital firms in 2004 to pour another USD 82 million 
into Alibaba in support of its e-commerce business expansion. This round of financial injection came at moment when eBay's joint venture inside China eachnet.com (Yiqu Wang) controlled $80 \%$ of China's burgeoning online consumer-to-consumer (C2C) market. As a counteroffensive against eBay, Alibaba used the funds to establish its own C2C platform called Taobao.com. Of the USD 82 million in acquisitions, USD 60 million from Softbank was used to develop Taobao.com (Jin 2010).

The next round of financial boosting, which came barely a year later, was even more impressive. In August 2005, Yahoo sold all of its China-related businesses and its brand and intellectual property rights to Alibaba. This sale was coupled with a USD 1 billion cash investment, the largest that Alibaba had ever received, in exchange for $40 \%$ of Alibaba's shares. After that round of financial acquisition, Softbank owned $29.3 \%$ of the shares while Ma and the other company founders owned the remaining 30\%, although corporate control was exercised by Ma and his Chinese fellows. Of the four members of the board of directors, Yahoo and Softbank each had only one seat, taken by both Yahoo's Taiwanese-American co-founder Jerry Yang and Masayoshi Son, while Alibaba's founders and managers, despite their minority shareholding, had two (Wang et al. 2011b). Furthermore, Softbank had relinquished its voting rights, while Yahoo's 40\% in shareholdings was only equipped with $35 \%$ of the voting rights (Wang et al. 2011b). In other words, the Chinese founders and managers controlled $65 \%$ of the voting rights.

Selling $40 \%$ of the company's shares to Yahoo presented a challenge to Ma Yun and his Chinese associates. To safeguard his authority, and more broadly, the Chinese founders and management team's control over the company, Ma held a private meeting with Jerry Yang at Pebble Beach Golf Links to confirm that Yang and Yahoo "have no intention of meddling in Alibaba's daily operations" (Su 2014). As a result, in addition to the voting mechanism described above, special clauses were added into the agreement between Alibaba and Yahoo to consolidate Chinese control, stating that under no circumstances could Ma Yun be stripped of his CEO position by the board of directors until October 2010 (Wang 2011). The clause actually emboldened Ma to harm Yahoo and Softbank's interests by stealing Alipay-a case that we will soon look at in later sections.

Of the USD 1 billion that Yahoo invested in Alibaba, only USD 250 million was used to fuel Alibaba's business expansion. The rest was divided for the purpose of rewarding the foreign financial investors that had funded Alibaba in previous rounds. Investors such as Goldman Sachs, Investor AB, and California-based Fidelity Capital sold their shares in Alibaba and earned a total of USD 570 million. Compared with the initial investment of USD 32 million made into Alibaba, the return rate was an unimaginable $1780 \%$ (Wang 2011). Softbank also sold part of its holdings and gained USD 180 million while still holding $29 \%$ of the shares (Wang 2011).

In November 2007, Alibaba listed the business-to-business (B2B) chunk of its ecommerce business on the HKSE and managed to raise USD 1.7 billion. It was also when early venture capital and private equity investors exited by selling their shares to public investors, earning them "ten times" their initial investment (Su 2014). However, Yahoo's cordial relationship with Alibaba, a bond previously sustained through the personal friendship between Ma Yun and Jerry Yang, soured after the latter stepped down as Yahoo's CEO in 2009. Yang's successor, Carol Bartz, openly chastised Ma Yun for failing to properly manage Yahoo China and "wanted Yahoo's brand in China back" (Fletcher 2009).

To ward off Bartz's threat to increase Yahoo's corporate influence on Alibaba, Ma Yun invited other financial investors to buy Alibaba's shares and dilute Yahoo's holdings. In the fall of 2011, financial investors such as California-based Silver Lake, Moscow-headquartered DST Global, Singapore's sovereign fund Temasek, and Shanghai-based and Ma Yun-cofounded YF Capital dispensed a total of USD 2 billion to purchase $5.7 \%$ of the shares held by Alibaba's management team and employees while renouncing their voting rights (Liao and Ding 2012). On 20 May 2012, Alibaba and Yahoo reached an agreement that allowed Alibaba to buy back up to half of Yahoo's stake in Alibaba, or approximately 20\% of Alibaba's total shares. The deal was finalized on 18 September 2012 at a price of approximately USD 
7.1 billion that included USD 6.3 billion in cash and up to USD 800 million in Alibaba's newly issued preferred stock (Alibaba 2012b). Additionally, Alibaba was given the right to a further buyback of half of Yahoo's remaining shares once Alibaba's IPO on the NYSE was completed (Alibaba 2012a).

To collect the money that would be used to buy back Yahoo's ownership, Alibaba sold ordinary shares worth USD 2.6 billion (7.2\% of the total) in two batches in August 2012 and then issued transferable shares worth USD 1.688 billion to financial investors (Su 2014). The names of the investors have not been disclosed, but they included 12 international hedge funds, private equity firms, mutual funds, and sovereign wealth funds, among which old investors such as Silver Lake, DST and Temasek were included, allowing them to increase their shareholdings (Su 2014).

Compared with the previous rounds in which investors were foreign-owned and -based financial institutions, the new shareholding buyers came from Chinese states, but also included a larger cohort of international investment banks. ${ }^{9}$ According to an anonymous fund manager, the consortium of those from Chinese states acquired $5 \%$ of the equity shares from Alibaba, among which the China Investment Corporation (CIC), a central stateowned sovereign wealth fund, purchased the largest number of ordinary shares because "Alibaba badly needed cash to kick Yahoo away, and the CIC was an optimal choice as it had faith in Alibaba's financial business and did not seek to meddle in its operations"; therefore, the two reached an agreement on further share-buying during the IPO (Qin and Jiadai 2013). As for the China Developmental Bank (CDB), a central state-owned policy bank that often funded massive Chinese infrastructural projects, Alibaba had relied on its help two months earlier when privatizing and delisting its B2B arm from the HKSE as part of a recapitalization plan to make the NYSE IPO more appealing. Out of the USD 2.5 billion that Alibaba spent to purchase and delist its publicly floated shares (Alibaba 2012a), only $20 \%$ came from Alibaba's own coffers. The remaining $80 \%$ came from banking loans, among which the CDB provided USD 1 billion and the other USD 1 billion came from eight international banks that all wanted to become Alibaba's underwriters. Eventually, only six international investment banks managed to be bookrunners for its IPO, sharing USD 300.4 million as part of a commission of $1.2 \%$ of the total deal (Barrero 2014).

After the last round of pre-NYSE IPO financing in 2012, Alibaba's ownership structure changed, with Yahoo's shareholdings dropping to 23\% and Softbank still holding 31.9\%, thus together giving non-Chinese investors the majority of shares in Alibaba (Liao and Ding 2012). As per the purchasing agreements signed with Alibaba's leadership, the company's new financial investors all willingly abandoned their voting rights and seats in the board of directors in exchange for high returns from Alibaba's IPO.

In November 2019, Alibaba's HKSE listing gave it the biggest fundraising of the year. The transaction was made against the backdrop of escalating trade and tech hostilities between China and the U.S., which led some observers to argue that the secondary listing was "politically motivated" (Nuttall 2019), driven by Beijing's dictates to be "a good corporate citizen and shrewd operator" and to "bolster Hong Kong" amid months of prodemocracy protests and turmoil (He 2019). The other proposed explanation for why the secondary listing only became feasible in 2019 was because the HKSE had revised its listing rules and had allowed listing companies with weighted voting rights (WVR) since 30 April 2018 (Hong Kong Exchanges 2018). This new rule, according to a financial journalist, "let individuals who were founders or key management of companies to hold shares with more voting rights or weight than other regular shareholders" (Yiu 2020), which was actually one of the issues that hampered Alibaba from listing on the HKSE in the first place in 2014, as it was incompatible with Alibaba's core corporate decision-making mechanism.

Despite multiple rounds of foreign investment injection, Alibaba was always firmly under the complete control of Ma Yun and his Chinese associates. 


\section{The Board over the Board: The Lakeside Partner (Hehuoren) Panel}

So what was the decision-making mechanism that obstructed Alibaba from listing on the HKSE in the first place? How exactly would the Chinese founders and managers of Alibaba guarantee that, despite their minority shareholding, corporate control would always rest in their hands? Like American Internet giants Google and Facebook (Govindarajan et al. 2018), most China-based and Chinese-controlled companies use a preferential stock structure $(A / B G u)$ with unequal and weighted voting rights in the Annual General Meeting to consolidate decision-making authority within a small China-based leadership group. However, the one used by Alibaba was even less transparent and institutionalized, which gave its effective controllers more discretionary power in making key decisions behind the backs of board members. It is perhaps common sense that a board, referring to a panel of elected individuals representing shareholders in corporate management and oversight, is the highest decision-making body in a firm. However, Alibaba has installed a uniquely designed top-down approach to intervene in the composition of board members known as "lakeside partnership" (Hupan Hehuoren), thus making the board of directors a secondary puppet organization inferior to the company's founders and managers.

Alibaba's internal decision-making and power structure have long been mysterious. However, to fulfil the U.S. Securities and Exchange Commission's (SEC) listing requirement, Ma Yun disclosed details about the Hehuoren institution on 10 September 2013 via an internal e-mail to Alibaba's employees (Ma 2013b; Liu and Wang 2014). According to the email, the Hehuoren institution was established in July 2010 and named after Ma's residence, which was adjacent to Hangzhou's West Lake, where the company was founded. As Figure 3 below shows, the major influences behind the top decisions made by Alibaba's board of directors were the selectorate Hehuoren panel of around 30 members, and Ma Yun and Joseph Tsai in particular. The Hehuoren panel's membership was not fixed and changed from time to time due to the election of new partners and the retirement or departure of incumbent partners. The panel admitted new members each year, and the nomination of new members could only be carried out by existing partners, who were able to propose new ones to the committee. After reviewing the nominations, the Hehuoren committee would decide whether the slate would proceed to the entire panel for voting. Then, all incumbent partners would vote on a one-partner-one-vote basis, with candidates that received an approval of more than $75 \%$ becoming new partners. In terms of eligibility, candidates needed to have at least five years of continued service with Alibaba or affiliated companies and their own equity interests in the company. Additionally, candidates were required to demonstrate a "high standard of personal character and integrity, maintain a 'track record of contribution to the corporate business', and serve as a 'culture carrier' committed to Alibaba's mission, vision, and values".

The core part of the Hehuoren selectorate is a self-nominated committee responsible for administering Hehuoren elections. The committee members serve a three-year term that can be renewed indefinitely (Securities and Exchange Commission 2014). Prior to the committee election that occurs every three years, the incumbent committee nominates a number of partners equal to the number of incumbent committee members to serve the next tenure, as well as three additional nominees. The slate is then passed to each member of the Hehuoren panel, and they are required to eliminate three and vote out a number equal to the number of incumbent committee members. In other words, the three nominees who receive the least votes from the Hehuoren members will not serve in the next mandate. All ordinary Hehuoren members are required to retire at the age of sixty or upon the termination of their qualifying employment. The Hehuoren committee can designate retired members as honorary partners, and they may be entitled to allocations from the deferred portion of the annual cash bonus pool as retirement pension payments. 


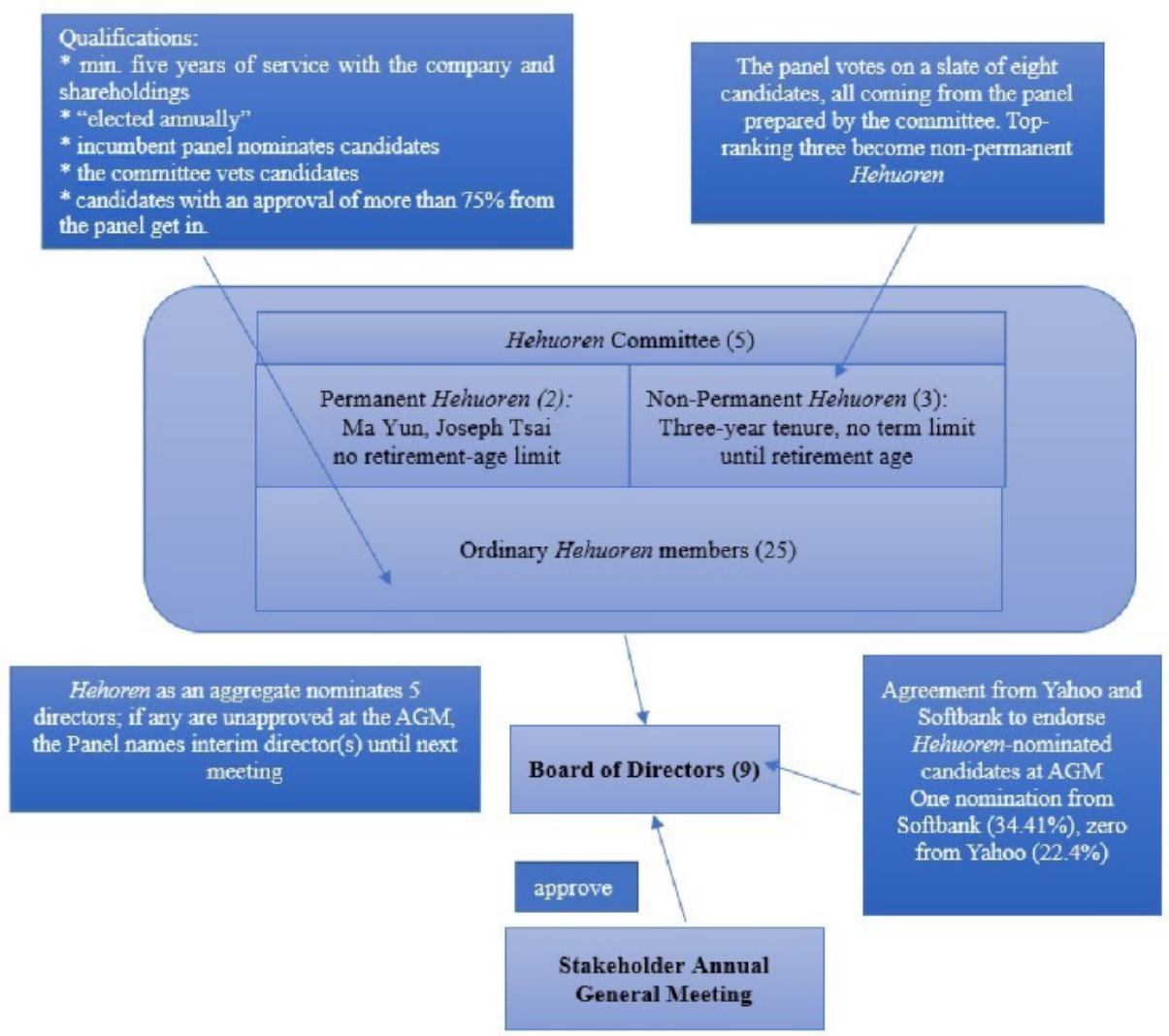

Figure 3. Power Structure of the Alibaba Hehuoren Panel in 2014. Source: Securities and Exchange Commission (2014); Hong Kong Stock Exchange (2019).

However, exceptions are granted to permanent Hehuoren who are the most powerful and elitist in Alibaba and are able to serve until they voluntarily retire, die, or become incapacitated. According to the Hehuoren Charter, "either two or three partners at a time may be designated as continuity partners, with Ma Yun and Joseph Tsai serving as the initial continuity partners [read as permanent Hehuoren]". To become a permanent Hehuoren, the candidate must be nominated by a retiring or incumbent permanent Hehuoren, put differently, only Ma and/or Tsai. A Hehuoren member, whether they are permanent or ordinary, may also be removed by a simple majority vote from all Hehuoren present at any duly-called meeting regarding the violations of certain standards set forth in the Hehuoren agreement. However, the Hehuoren Charter does not mention how the meeting can be convened and who can do so. Furthermore, any amendment to the Hehuoren agreement requires an approval of $75 \%$ by attending partners and must be done so at a meeting where at least $75 \%$ of all partners are in attendance.

There are two ways in which Hehuoren as a collective can exert effective control over Alibaba. The first comes from its unchallengeable power to shape the board composition. For instance, the Hehuoren panel has the exclusive right to nominate a simple majority of the members on the board of directors. Although the election of each director-nominee for Hehuoren is subject to a majority vote from shareholders at an Annual General Meeting, Hehuoren has the right to appoint a different person to fill the vacancy until the next Annual General Meeting in the case that a director-nominee is not elected or quits the position after election. If Hehuoren's nominated or appointed board directors do not form a majority, Hehuoren has the discretionary power to appoint additional directors to the board to ensure that their appointees always take majority.

Hehuoren's nomination power makes them almost impossible for outside members to challenge, because any revisions to such clauses require $95 \%$ of the shareholders to vote in favor of them at an Annual General Meeting. In fact, Ma Yun could veto such an initiative 
entirely by himself, as he held $8.8 \%$ of Alibaba's total issued shares at the time of the NYSE IPO. Thus, Ma himself could turn down any proposals against Hehuoren's interests. In other words, as long as Hehuoren's aggregate shareholding was above 5\%, their dominance over the board's composition was unshakable. In the 2014 IPO Prospectus, Alibaba made this point crystal clear, as "the nomination rights of the Alibaba Partnership [read as the Hehuoren Institution] and the voting agreement will limit your ability to influence corporate matters, and the interests of the Alibaba Partnership may not coincide with your interests".

As shown in Table 3 below, Alibaba's board had nine members upon the completion of the company's IPO in 2014. As per the nomination clause, Hehuoren could nominate a majority of five, although it chose to nominate four. ${ }^{10}$ However, after the IPO, Hehuoren appointed another two board members and increased the total number of directors to eleven. Through a voting agreement, Softbank, which had only one board member, agreed to vote in favor of the Hehuoren-proposed nominees at each Annual General Meeting as long as it held at least 15\% of Alibaba's outstanding ordinary shares. In addition, if Softbank gained more than $30 \%$ of the outstanding ordinary shares, the voting weight, which was correspondent to the portion beyond 30\%, would be granted to a trust company that was owned and controlled by Ma Yun and Joseph Tsai, both of whom were Alibaba's permanent Hehuoren. However, if Softbank's holdings dropped below 15\%, it would lose its only seat in the board (Pengpai 2014). Yahoo, unfortunately, had no seat on Alibaba's board. ${ }^{11}$

Table 3. Composition of Alibaba's Board (2012-2020).

\begin{tabular}{|c|c|c|}
\hline & Directors of the Board & Expiration of Three-Year Term \\
\hline Group I & J. Tsai *, Lu Z. *, M. Evans *, $(+$ B. Ekholm $)$ & Annual General Meeting of 2021, 2018, 2015 \\
\hline Group II & Zhang Y. * C. H. Tung, J. Yang, (+W. L. Martello) & Annual General Meeting of 2022, 2019 \\
\hline Group III & Ma Y. *, M. Son ^, W. Kwauk & Annual General Meeting of 2020, 2017 \\
\hline \multicolumn{3}{|c|}{$\begin{array}{l}\text { * Hehuoren nominee, ^ Softbank nominee; Ekholm was added on the board in June 2015, Martello in September 2015; } \\
\text { Ma Yun was replaced by Maggie Wei Wu * in September 2020; Lu Zhaoxi replaced by Jing Xiandong * in September } \\
\text { 2016; Masayoshi Son replaced by Kabir Misra ^in September 2020. Source: (Securities and Exchange Commission } \\
\text { 2014), Alibaba Group, Corporate Governance. https:// www.alibabagroup.com/en/ir/governance_6 (accessed } \\
\text { on } 15 \text { September 2020). }\end{array}$} \\
\hline
\end{tabular}

Alibaba also adopted an anti-takeover design that could ward off the possible reshuffling of board membership that could challenge Hehuoren's domination over its composition. ${ }^{12}$ As the table above shows, the board of directors is divided into three groups designated as Group I, Group II, and Group III with the number of directors in each group being roughly equal. Directors assigned to Group I initially serve until the first Annual General Meeting of shareholders following the completion of the 2014 IPO. In a similar vein, directors assigned to Group II would serve until the second post-IPO Annual General Meeting of shareholders, and directors assigned to Group III would initially serve until the third Annual General Meeting.

The other way in which Hehuoren controlled the company was that all of its members simultaneously held important managerial positions in the affiliated companies operating inside China. In fact, Alibaba acknowledged that the Hehuoren panel was "largely comprised of members of our management team" (Securities and Exchange Commission 2014). The managerial portfolios of Hehuoren members manifest such overlapping. According to Alibaba's IPO Prospectus, the core assets of the 2014 IPO included three online retail market sites (Taobao, Tmall, and Juhuasuan), three wholesale online sites (AliExpress, Alibaba, and 1688), Zhejiang Ant Small and Micro Financial Services Company, the cloud computing service Aliyun, and the shipping and delivery operator China Smart Logistics. As Table 4 below shows, Hehuoren members all held key positions in either the Alibaba Corporation or the affiliated companies that managed listed assets. 
Table 4. 30 Hehuoren Members, Their Positions and Shareholdings in Alibaba in 2014.

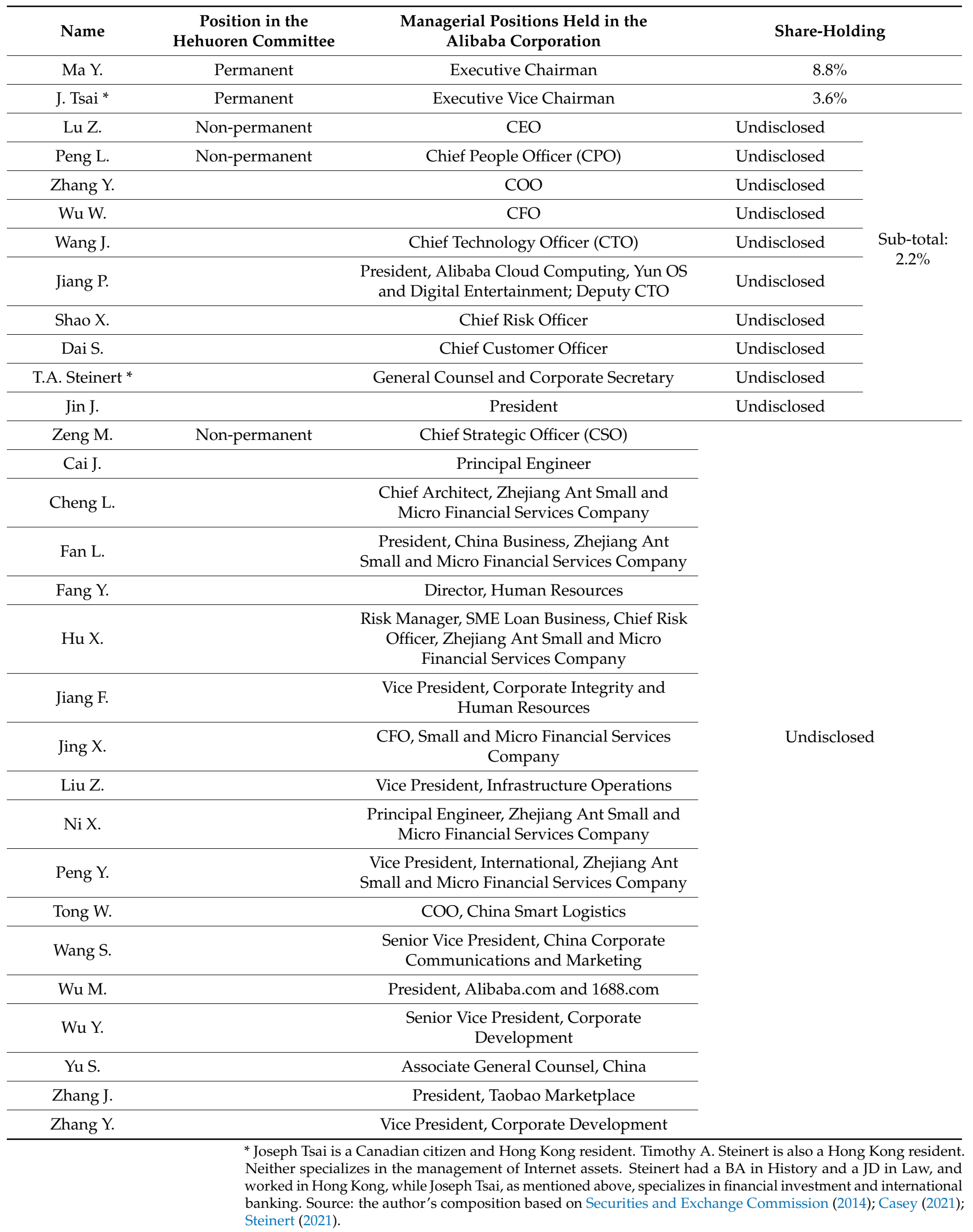


To sum up, compared with the preferential stock structure that only granted Chinabased founders voting privileges in the Annual General Meeting and the transparency of the weighted voting and voting process in the Annual General Meeting, Alibaba's Hehuoren system had gone further by concentrating corporate control into a handful of company founders and managers. This design made the Chinese founders more influential in corporate matters and weakened the Annual General Meeting's power in electing board members. In fact, the majority of corporate decisions were not made during the Annual General Meeting but worked out at the board level. Therefore, dominating the board meant controlling the entire company. This point is uttered straightforwardly in their IPO documents to investors. Share ownership does not equate to voting rights, a design that, as the prospectus explicitly states, "will limit your [investors'] ability to influence corporate matters, including any matters determined at a board level" (Securities and Exchange Commission 2014).

\section{When a "False Divorce" Became True: The Alipay Case}

What would happen to foreign investors that owned the majority shares but could not operate or control their assets inside China? The Alipay (Zhifu Bao) case offers an answer. As an e-commerce giant, Alibaba boasts a PayPal-like online payment tool named Alipay. This software is central to the entire business empire because it provides payment services for all B2B, B2C, and C2C services. All of the business on Taobao, Alibaba's e-commerce platform, goes through Alipay. According to a firm analyzing market shares, Chinese market transactions through third-party payments reached RMB 1.132 trillion in 2010, with Alipay boasting half of the market share ( $\mathrm{Pu} 2011$ ).

The Alipay controversy started with a decision made by Ma Yun to unilaterally end the VIE agreement between the Cayman Islands-registered Alibaba Corporation and the Alipay E-Commerce Corporation and then spin off Alipay as a separate Chinese-registered and -owned company. Before Ma's action, Yahoo and Softbank together owned more than $70 \%$ of Alipay's shares. However, in two separate instances on 1 June 2009 and 6 August 2010, Ma used his dominance over Alibaba's assets inside China and the power granted by the Hehuoren system to spend a total of RMB 330 million to transfer the Alipay assets from a China-based wholly foreign-owned enterprise established by the Alibaba Corporation on paper to Zhejiang Alibaba Commerce, a completely domestic company founded in October 2000 (Wang et al. 2011a). This Zhejiang-registered company was fully owned and controlled by two Chinese citizens, with Ma Yun himself owning $80 \%$ of the RMB 710 million in registered capital and Xie Shihuang owning the rest. As stated in earlier sections, the VIE structure was based on contractual arrangements rather than equity ownership, so the parent company (i.e., the Cayman Islands-registered Alibaba Corporation) had no obligation to inform foreign investors of such decisions. However, the cost was colossal for all foreign shareholders, especially Yahoo and Softbank, who would lose out on any direct benefit from launching Alipay and its future IPO. ${ }^{13}$

Why did Ma make such a dishonest move? Ma defended himself by saying that the third-party payment platform's pending parchment regulation with the People's Bank of China (PBoC), China's central bank, was the major reason. As early as 2006, the PBoC had released its first draft of the third-party payment regulation and sought public comments. Various rounds of revision had taken place since then, and the PBoC had permitted Chinabased and Chinese-controlled companies like Alibaba to operate such business despite an absence of written rules. Allegedly, Ma was obliged to make Alipay a fully Chinese-owned and -controlled company in anticipation of the need to avoid contravention with the PBoC's pending policy, which would require third-party payment providers to obtain an operating license, something prohibited to foreign investors.

On 14 June 2010, the PBoC officially unveiled the much-awaited written text, which stipulated that any firm providing third-party business payment must apply for an operating license from the $\mathrm{PBoC}$, and that the applicant must be "a limited liability company or joint-stock company legally established inside the People's Republic of China as the 
corporate body of a non-financial institution" (People's Bank of China 2010). However, the document intentionally skewed the question of whether foreign investment was allowed in such business and whether an equity cap applied in that case. Rather, it stated that, "the business scope of foreign-funded payment institutions, the eligibilities of overseas investors, the ratios of the investments of overseas investors, and other such matters shall be determined by the PBoC in other initiatives and be submitted to the State Council for approval" (People's Bank of China 2010).

One of the major reasons why the written regulation took four years to come out was because the different ministries failed to reach a consensus on what percentage of ownership foreign investors should be allowed to have in third-party payments. One option was 50\%, in accordance with the equity cap of the Ministry of Industry and Information Technology (MIIT) on telecom value-added services (Wang 2011). The other option was 20-25\%, based on the foreign equity granted to banking and financial institutions that agreed that no single foreign shareholder could surpass $20 \%$ and that their aggregate shares could not surpass 25\% (Wang 2011).

Eventually, a fixed numeric benchmark was not written into the policy. The deeper reason, according to one industrial insider's interpretation, was related to China's World Trade Organization (WTO) commitment and practical protectionist considerations (Wang et al. 2011b). China did not make any commitment in opening its payment sector when gaining their WTO membership in 2001. In 2010, the American credit card company VISA was still in a row with its Chinese equivalent Union Pay, which was yet to be adjudicated by the WTO. ${ }^{14}$ Although technically speaking, third-party payment does not include banking payment, the Chinese government believed that if the PBoC accepted foreign equity in third-party payments and allowed foreign investors to apply for an operating license, it would run counter against and weaken its official stance in the Union Pay issue (Wang et al. 2011b).

Since the PBoC's parchment regulation did not specifically mention how VIE companies were to be regulated, Alibaba promptly communicated with the PBoC and was told that if the license-applying company contained a foreign equity investment, it must obtain approval from the State Council, rather than the PBoC alone (Wang et al. 2011a). Going through the State Council meant that the vetting and approval of many more stake-holding ministries would be involved. According to Alipay's CFO Jing Xiandong, Alibaba decided to spin off Alipay from the Cayman Islands-registered Alibaba Corporation and transfer the assets to the purely domestically registered and Chinese-controlled Zhejiang Alibaba "out of fear for the risks and waiting time" (Wangyi 2011). In fact, spinning off Alipay was communicated to and endorsed in a board meeting on 24 July 2009, with Masayoshi Son and Jerry Yang permitting it, "as long as a VIE contractual relationship existed" (Wangyi 2011). In other words, Yahoo and Softbank gave their consent on the condition that the spinoff was merely a tactic to obtain the operating license and that future profits, would be transferred back to the Alibaba Corporation in the Cayman Islands.

On 6 August 2010, Ma Yun transferred the remaining 30\% of Alibaba's ownership to Zhejiang Alibaba, thus turning Alipay into a full subsidiary of Zhejiang Alibaba. However, until this moment, the spun-off Zhejiang Alipay, the company that held Alipay's assets, was still under VIE contracts. The second transfer took place when Hehuoren's nominees (i.e., Ma Yun and Joseph Tsai) still dominated the four seats of the board membership. In October 2010, the voting agreement that Alibaba signed with Yahoo in 2005 expired, and Yahoo was now able to add one more member, making it on par with Hehuoren. As some observers pointed out, control over Alibaba, the status of Alipay, and the board membership change were not in isolation, but were "the same chess game played by Ma Yun" (Wang et al. 2011b).

Ma went further. In late January 2011, imminent to the official release of its third-party payment licenses, the $\mathrm{PBoC}$ requested all the recipients it had vetted to submit written declarations on whether any capital outside China had exerted control over the companies through shareholdings, contracts, or other arrangements (Wang et al. 2011b). According 
to a source at the $\mathrm{PBoC}$, the move was merely for the purpose of filing documents and to check if any non-Chinese entities were exerting any real control over the licensed company. There was no intention or insinuation that the existence of a VIE would nullify the license (Shi 2011). On the day before the submission, Ma Yun unilaterally ended the VIE contract between Alipay and the Cayman Islands-registered Alibaba Corporation. However, Yahoo, one of the major shareholders of Alibaba, was kept in the dark about this for about two months. Yahoo alleged that Alibaba's notification on ending the VIE contract did not come until 31 March and that it was not approved by either the board or the shareholder meeting. Due to the large slice of valuable assets in Alibaba that Yahoo lost, the company's share price plunged on 11 May by $7.28 \%$, followed by a $6.23 \%$ nosedive the following day (Wang et al. 2011a).

The reason why Ma Yun could spin off such valuable assets from the holding company without even being noticed by major foreign investors was because under the VIE design, the fully Chinese-owned and -controlled VIE company that could apply for and hold government-issued licenses and the wholly foreign-owned enterprise that the foreign holding company established as an affiliate inside of China were essentially one institution with two names. In other words, the six contracts that bound Zhejiang Alipay and the Cayman Islands-registered Alibaba Corporation together were all signed by the same person, Ma Yun, under two different names. Furthermore, they could also all be terminated and declared void by Ma himself.

In public, Ma Yun had used the PBoC's policy as a pretext to justify enhancing Hehuoren's interests at the expense of foreign investors. On 14 June 2011, Ma defended his actions in a press conference, saying that the decision was "very difficult but the only responsible way" because "a [third-party payment] license applicant with foreign investment would need the State Council's approval, which takes a long time. A refusal could jeopardize the tens of thousands of e-commerce websites operated by Alibaba" (Wangyi 2011). Therefore, Alipay "must be one of the first applicants to obtain the license in a secure and legal way without any fluke mind" (jiaoxing xinli); and to achieve this end, "200\% of the efforts must be made to ensure 100\% of the final result" (Wangyi 2011). Moreover, Ma said that "for the first time, I respect the PBoC's consideration over national security" regarding the regulations on third-party payments.

However, Ma's allegations were spurious. Among the other 26 companies that obtained third-party payment licenses together with Alipay, half of them resorted to foreign investment via the VIE model in the same way Alibaba did. Regarding the five applicants that did not receive the license, the reason was simply because of the late submission of application materials (Wang et al. 2011b). Even for the regulator, Ma Yun's "national security" justification and the alleged risk of Alipay being shut down "was nothing but fearmongering" (weiyan songting), because all the applicants had disclosed their foreign shareholding status and VIE structure to the PBoC in early 2011 (Wang et al. 2011b). In fact, several officials from the PBoC disclosed that although the PBoC had demanded that the license applicant and holding company should not have any direct or indirect shareholdings from foreign investors, it did not treat the VIE model as foreign shareholding and control (Wang et al. 2011b). Moreover, since Alipay was the dominant player in third-party payments, the PBoC's officials even acknowledged that the regulator "frequently consulted with Alibaba throughout the process of drafting the regulation" and that the final version was "substantially influenced" by Alipay's interest and stance (Wang et al. 2011b).

In a calm dénouement, no legal action was pursued. Rather, an agreement was reached between Ma Yun and Alibaba's major shareholders Yahoo and Softbank. As compensation, the Cayman Islands-registered Alibaba Group would license technology services and intellectual property to Alipay, and in return, Alipay would pay royalties to Alibaba. Moreover, once Alipay got their IPO, Alibaba would get no less than USD 2 billion and no more than USD 6 billion in proceeds (Dignan 2011).

Ironically, a controversy that was caused by contracts was, again, resolved by another contract. 


\section{Concluding Remarks}

The objective of this article is to show how the globalization of financial markets has contributed to a particular form of cross border capital flow that I call ODFF. I have also shown that, as a particular variant of ODFF, VIE allowed Chinese entrepreneurs and management teams with negligible share ownerships to have disproportionate dominance over corporate decision-making and management against non-Chinese financial investors who held the majority of shares. This was achieved through the indistinguishable relationship between the wholly foreign-owned enterprise and VIE as they were essentially the same institution under two different names staffed and controlled by the same group of Chinese entrepreneurs and managers.

Another key finding is that depriving foreign investors of their corporate control over assets inside China benefitted the Chinese company founders and management teams. As Ma Yun once openly claimed, "there is no problem if you want to buy shares, but I must be the person controlling the company; otherwise, I do not need your investment. You can be the shareholder, but do not meddle with anything in the company" (shenme dou buyaoguan) (Wang 2011). In reality, as the Alibaba case reveals, the board of directors was reduced to a puppet through the Hehuoren design, thus allowing Ma Yun and his management team, who owned less than $20 \%$ of the aggregate stock, to leverage and tightly control the entire corporation.

The paragraphs above have also shown how ODFF challenges our conventional understanding of "foreignness" as related to transnational investment, in a sense that the fund-absorbing SPVs established in OFCs are concomitantly foreign investment recipients and initiators. The offshore status of ODFF means that capital acquisition takes place outside of China's borders and that global investors do not directly invest into the target company via China's financial market. China's domestic capital markets remain largely closed off to global investors. Thus, they are shielded from the risks associated with sudden foreign capital outflow that many developing economies have encountered after liberalizing their domestic financial markets.

Finally, it is noteworthy that the analysis in this article is limited to the transnational corporate structure of Chinese Internet firms with Alibaba as an example. This inevitably leaves some important questions unanswered. For instance, this article only reveals that the convoluted VIE structure helps to make the companies Chinese-controlled, but it does not show how the Chinese regulators tell VIE-users from foreign-controlled companies. Therefore, more research is needed to present a historical account on the specific measures that the Chinese regulators have taken to allow such legally ambiguous and risky corporate structures to exist and function, and grant them special treatment as Chinese domestic companies in terms of business registration, taxation, and operating license application. Moreover, this article examined the VIE structure through the lens of cross-border foreign capital flow. However, the fact that large shareholding foreign investors nominally own a company but cannot exert substantial corporate control can also be understood through the concept of property rights. In other words, the Alipay case can also be framed as an issue that VIE has enabled and emboldened Ma Yun and the Hehuoren to expropriate foreign assets. The relationship between foreign investment inflow in the form of ODFF and the investors' property rights execution in China's Internet industry is another promising subject for future scholarly inquiries.

Funding: I note with gratitude financial support from the Social Sciences and Humanities Research Council of Canada's doctoral fellowship 752-2020-2387, and Graduate Student Fellowship offered by Centre for Global Studies of University of Victoria (2019-20).

Institutional Review Board Statement: Not applicable.

Informed Consent Statement: Not applicable.

Data Availability Statement: Not applicable.

Conflicts of Interest: The author declares no conflict of interest. 


\section{Notes}

This record was only surpassed by Saudi Armco's USD 29.5 billion five years later.

According to the guidelines established by the Organization of Economic Co-operation and Development (OECD), a minimum of $10 \%$ ownership stake in a foreign-based company is the threshold for a cross-border investment transaction to be qualified as a FDI that establishes a controlling interest. For a more detailed definition, see, (OECD n.d.), Foreign Divestment Investment Statistics: Explanatory notes, https:/ / www.oecd.org/daf/inv/FDI-statistics-explanatory-notes.pdf (accessed on 20 July 2019).

3 In the entire project, I use "foreign" from a corporate control perspective rather than a purely geographical one. Expressions such as "foreign companies" or "foreign investors" refer to non-Chinese controlled and outside-China headquartered firms, thus excluding the offshore SPVs set up for funding purposes by China-based and Chinese-owned companies.

4 Under certain conditions, the investments from Hong Kong-registered companies in Mainland China can benefit from a 5\% tax deduction. The Mainland and Hong Kong Closer Economic Partnership Arrangement (CEPA) signed in 2003 granted qualifying products, companies, and residents of Hong Kong preferential access to the Mainland.

5 Among all the contracts, the equity-pledge agreement must be reported to the Chinese regulator; two parties must sign the others on a voluntary basis.

6 This risk is articulated in the IPO prospectus of all foreign-incorporated and -listed companies based in China. For instance, Alibaba's prospectus for the NYSE listing in 2014 stated that “The Company [Alibaba Group Holding Limited] is incorporated in the Cayman Islands and considered as a foreign entity under PRC laws. Due to the restrictions on foreign investment and ownership on the business related to Internet content provision, telecom value-added services, financial services and others, the Company conducts its business through various contractual arrangements with VIEs that are generally owned and controlled by management members of the Company. The VIEs hold the licenses and approvals that are essential for their business operations in the PRC and the Company has entered into various agreements with the VIEs and their equity holders such that the Company has the right to benefit from their licenses and approvals and generally has control of the VIEs" (Securities and Exchange Commission 2014).

7 Based on the author's own calculation based on U.S.-China Economic and Security Review Commission (2021).

8 Ibid. Also, based on a survey conducted in March 2019, of the 182 surveyed Chinese companies that were listed on NASDAQ and NYSE, 125 (69\%) of them used the VIE structure (Gills and Oqvist 2019).

9 Alibaba is one of many Internet companies funded by Chinese state agencies or relatives of Chinese top-leadership, who made good fortunes from the companies' overseas IPOs. As per the company's 2012 round of fundraising, Boyu Capital, a private equity firm that invested over USD 100 million, was co-founded and co-owned by Jiang Zhicheng, grandson of former CCP Secretary General and Chinese president Jiang Zemin. For more information, see, for instance, Mitchell et al. (2012); Forsythe (2014); Kane (2021).

10 Michael Evans served as the independent director nominated by the nominating and corporate governance committee upon the IPO. Afterwards, he became a Hehuoren nominee (Securities and Exchange Commission 2014).

11 Jerry Yang was the Yahoo nominee on Alibaba's board from October 2005 to January 2012. He left Yahoo in 2012 and was invited back on Alibaba's board in 2014 as an independent director.

12 For more information on how classfied boards as a defensive tool against take over, see Faleye (2007).

13 Alipay was restructured and named Ant Finance. However, in October 2020, the Chinese central authority halted its dual listing on the Shanghai and Hong Kong securities exchange just days before the scheduled date. For more information, see (Yang and Wei 2020).

14 For more information on this dispute and WTO's settlement, see, (World Trade Organization n.d.) “DS413: China—Certain Measures Affecting Electronic Payment Services." https://www.wto.org/english/tratop_e/dispu_e/cases_e/ds413_e.htm (accessed on 24 September 2020).

\section{References}

Alibaba. 2004. China e-Commerce Leader Alibaba Raisees US\$82 Million form First-Tier Investors. February 17. Available online: https:/ / www.alibabagroup.com/en/news/press_pdf/p040217.pdf (accessed on 14 September 2021).

Alibaba. 2005. Alibaba Quanmian Shougou Yahu Zhongguo, 10Yi Meijin Dazao Hulianwang Sousuo [Alibaba Fully Merged Yahoo China, Splurging US\$1 Billion to Build Internet Search]. August 11. Available online: https://www.alibabagroup.com/cn/news/ press_pdf/p050811.pdf (accessed on 14 September 2021).

Alibaba. 2007. Alibaba Wangluo Youxian Gongsi Shouri Gaupai Jiaoyi [Alibaba Internet.Ltd Started Its First Day Trade]. November 6. Available online: https://www.alibabagroup.com/cn/news/press_pdf/p071106.pdf (accessed on 17 September 2021).

Alibaba. 2012a. Alibaba Jituan Wancheng 76 Yi Meiyuan Gufen Huigou Jihua, Yu Yahu Guanxi Jiekai Xinpianzhang [Alibaba Completed US\$7.6 Billion Share Buy-Back Plan, Opening a New Chapter with Yahoo]. September 18. Available online: https:/ / www.alibabagroup.com/cn/news/press_pdf/p120918.pdf (accessed on 19 September 2021).

Alibaba. 2012b. Yahoo! and Alibaba Reach Agreement on Comprehensive Plan for Alibaba Stake. May 20. Available online: https:/ / www.alibabagroup.com/cn/news/press_pdf/p120520.pdf (accessed on 19 September 2020). 
Bain, Benjamin. 2021. Gensler Warns of Chinese Company Risks after SEC Crackdown. Bloomberg, August 16. Available online: https:/ / www.bloomberg.com/news/articles/2021-08-16/gensler-warns-of-chinese-company-risks-following-sec-crackdown (accessed on 15 February 2022).

Barrero, Elzio. 2014. Alibaba IPO Underwriters Earn USD 300 Million in Fees, 1.2 Percent of the Deal. September 22. Available online: https:/ / www.reuters.com/article/us-alibabaipo-fees-idUSKCNOHH1EY20140922 (accessed on 20 February 2022).

Casey, Quentin. 2021. Who Is Joseph Tsai? The Canadian Man of Action behind Alibaba's Embattled Jack Ma. Financial Post, September 1. Available online: https:// financialpost.com/personal-finance/high-net-worth/whos-joseph-tsai-the-canadian-man-of-actionbehind-alibabas-embattled-jack-ma (accessed on 1 September 2021).

China National Radio. 2014. Hangzhou Shiwei Shizhengfu Fahexin Zhuhe Alibaba Chenggong Shangshi [Hangzhou's CCP Committee and Municipal Government Sent Congratulatory Letters for Alibaba's Successful IPO]. September 20. Available online: http: / / news.cnr.cn/native/city/201409/t20140920_516473326.shtml (accessed on 13 September 2020).

Collier, David. 2011. Understanding Process Tracing. Political Science \& Politics 44: 823-30.

Cui, Xi. 2014. Ali Shujv Yaodian: 2013nian Lingshou Jiaoyi'e 2480yi Meiyuan (Keypoints of Ali's Data: Retail Volume of Trade Reaching US\$248 Billion). Xinlang Keji, May 7. Available online: https: / tech.sina.com.cn/i/2014-05-07/05349363201.shtml (accessed on 16 February 2022).

Dignan, Larry. 2011. Alibaba, Yahoo, Softbank Settle Alipay Rift. Computer Network, July 29. Available online: https://www.cnet.com/ tech/services-and-software/alibaba-yahoo-softbank-settle-alipay-rift/ (accessed on 25 September 2020).

Ding, Yiyi, and Zhao Sun. 2011. Sadan VIE (Satan VIE). Shidai Zhoukan. Available online: https://www.163.com/tech/article/7IQGT5 340009387K.html (accessed on 22 September 2020).

Faleye, Olubunmi. 2007. Classified boards, firm value, and managerial entrenchment. Journal of Financial Economics 83: 501-29. [CrossRef]

Financial Accounting Standards Board. 2008. Interpretation No.46: Consolidation of Variable Interest Entities. Available online: https: / / www.fasb.org/jsp/FASB /Document_C/DocumentPage?cid=1175801627792\&acceptedDisclaimer=true (accessed on 14 September 2020).

Flannery, Russell. 2014. Inside Alibaba: Vice Chairman Joe Tsai Opens up about Working with Jack Ma and Jonathan Lu. Forbes, January 8. Available online: https:/ / www.forbes.com/sites/russellflannery/2014/01/08/inside-alibaba-vice-chairman-joe-tsaiopens-up-about-working-with-jack-ma-and-jonathan-lu/?sh=33e5ad49511b (accessed on 15 September 2020).

Fletcher, Owen. 2009. Yahoo, Alibaba relationship frays under Bartz. Computer World, May 19. Available online: https://www. computerworld.com/article/2525320/yahoo--alibaba-relationship-frays-under-bartz.html (accessed on 19 September 2020).

Forsythe, Michael. 2014. Alibaba's I.P.O Could Be a Bonanza for the Scions of Chinese Leaders. New York Times. Available online: https:/ / dealbook.nytimes.com/2014/07/20/alibabas-i-p-o-could-be-a-bonanza-for-the-scions-of-chinese-leaders / (accessed on 20 September 2020).

Gills, Paul. 2011. Explaining VIE Structures. China Accounting Blog, March 20. Available online: https://www.chinaaccountingblog. com/weblog/explaining-vie-structures.html (accessed on 22 September 2020).

Gills, Paul, and Fredrik Oqvist. 2019. March 13. Available online: https://www.chinaaccountingblog.com/weblog/2019-03-vie-gillis. pdf (accessed on 16 February 2022).

Gillis, Paul, and Michelle René Lowry. 2014. Son of Enron: Investors weigh the risks of Chinese variable interest entities. Journal of Applied Corporate Finance 26: 61-66.

Govindarajan, Vijay, Shivaram Rajgopal, Anup Srivastava, and Luminta Enache. 2018. Should Dual-Class Shares Be Banned? Available online: https:/ /hbr.org/2018/12/should-dual-class-shares-be-banned (accessed on 15 February 2022).

He, Laura. 2019. Alibaba's homecoming is about pleasing and buying trade war insurance. Cable News Neetwork, November 15. Available online: https:/ / www.cnn.com/2019/11/15/tech/alibaba-hong-kong-china-trade-war/index.html (accessed on 15 November 2019).

Hong Kong Exchanges. 2018. Hong Kong's Listing Regime Enters New Era, Featuring Emerging and Innovative Firms. April 24. Available online: https://www.hkex.com.hk/news/regulatory-announcements/2018/180424news?sc_lang=en (accessed on 25 September 2020).

Hong Kong Stock Exchange. 2019. Global Offering of Alibaba Group. November 15. Available online: https://www1.hkexnews.hk/ listedco/listconews/sehk/2019/1115/2019111500039.pdf (accessed on 19 September 2021).

Jin, Zhihui. 2010. Alibaba He Yahu de ‘Wu'nian Zhiyang' [Alibaba and Yahoo's 'Five-Year Itch']. Huanqiu Qiyejia. Reposted in Reuters. November 28. Available online: https://www.reuters.com/article/idCNCHINA-3414220101129 (accessed on 22 November 2020).

Johnson, Kaitlyn. 2014. Variable Interest Entities: Alibaba's Regulatory Work-Around to China's Foreign Investment Restrictions. The Loyola University Chicago International Law Review 12: 249.

Kane, Wu. 2021. Exclusive: Ant Investor Boyu Capital targets $\$ 6$ billion for new private equity fund-sources. Reuters, February 23. Available online: https://www.reuters.com/article/us-boyu-capital-fundraising-exclusive/exclusive-ant-investor-boyu-capitaltargets-6-billion-for-new-private-equity-fund-sources-idUSKBN2AO0KK (accessed on 20 February 2022).

Liao, Lingjun, and Mo Ding. 2012. Ali Hunxue (Mix-Blooded Alibaba). Huanqiu Qiyejia. Reposted in Reuters, October 15. Available online: https:/ / www.reuters.com/article/huanqiu-ali-mix-blood-idCNCNE89F05620121016 (accessed on 22 November 2020). 
Lin, Jun. 2009. Feiteng 15 Nian: Zhongguo Hulianwang 1995-2009 [15 Years of Boiling: China's Internet from 1995 to 2009]. Beijing: Zhongxin Chubanshe.

Liu, Xiaojing, and Xinci Wang. 2014. Alibaba IPO Qian Wugai Zhaogushu [Alibaba revised the Prospectus Five Times Before IPO]. Caixin, September 11. Available online: https:// companies.caixin.com/2014-09-11/100727355.html (accessed on 23 September 2020).

Ma, Mangwei. 2013a. The Perils and Prospects of China's Variable Interest Entities: Unraveling the Murky Rules and the Institutional Challenges Posed. Hong Kong LJ 43: 1061.

Ma, Yun. 2013b. Email Message to Alibaba's Employees. Quoted in Sina. “Alibaba Pilu Hehuoren Zhidu: Zhixing Sannian, Yiyou 28 Ren [Alibaba Disclosed its Partnership Institution: Three Years in Practice, Now Counts 28 Members]". September 10. Available online: https:/ / tech.sina.com.cn/i/2013-09-10/12308725122.shtml (accessed on 24 September 2020).

Market Watch. 2004. Tencent 158 Times Oversubscribed. Available online: https://www.marketwatch.com/story/china-tencent-ipo158-times-oversubscribed-afx (accessed on 15 February 2022).

Mitchell, Tom, Kinder Tabby, and Sevastopulo Demetri. 2012. Firm founded by Son of China finance tsar invests heavily in tech. Financial Times, May 18. Available online: https://www.ft.com/content/62554721-3b52-4cb9-8d1d-ccdf40b4e463 (accessed on 20 September 2020).

Nuttall, Chris. 2019. Alibaba's trade War IPO. Financial Times, May 28. Available online: https://www.ft.com/content/975df4c4-816711e9-b592-5fe435b57a3b (accessed on 23 September 2020).

Office of the Central Cyberspace Affairs Commission of China. 2018. Xi Jinping: Meiyou Wangluo Anquan Jiumeiyou Guojia Anquan [Xi Jinping: There is No National Security without Cyber Security]. December 27. Available online: http://www.cac.gov.cn/2018 -12/27/c_1123907720.htm (accessed on 22 July 2020).

Organization of Economic Co-Operation and Development (OECD). n.d. Foreign Divestment Investment Statistics: Explanatory Notes. Available online: https: / / www.oecd.org/daf/inv/FDI-statistics-explanatory-notes.pdf (accessed on 20 July 2019).

Pengpai. 2014. Shuide Ali: 28 Ge Hehuoren Ruhe Zhangwo Qainyi Diguo [Who Does Alibaba Belong to: How the 'Partnership' Controls the Empire That Worth Hundreds of Billions]. May 8. Available online: http://m.thepaper.cn/kuaibao_detail.jsp? contid=1245983\&from=kuaibao (accessed on 23 September 2020).

People's Bank of China. 2010. Administrative Measures for the Payment Services Provided by Non-Financial Institutions. June 14. Available online: http:/ / www.gov.cn/flfg/2010-06/21/content_1632796.htm (accessed on 25 September 2020).

$\mathrm{Pu}$, Jun. 2011. Nian Zhongguo Disanfang Zhifu Shichang Jiaoyi'e Po Wanyi [Chinese Third-Party Payment Market Surpassed 1 trillion Yuan in 2010]. Caixin, February 11. Available online: https:/ / companies.caixin.com/2011-02-21/100227311.html (accessed on 25 September 2020)

Qin, Wei, and Jiang Jiadai. 2013. Alibaba Guquan Biangengshi: Zhongtou Guokaihang Deng Guojiadui Shenmi Rugu [History of Alibaba" Stock Holding Change: National Team of CIC and CDB Mysteriously Bought Shares]. Ershiyi Shiji Jingji Baodao. Reposted by Sina. July 25. Available online: http:/ / finance.sina.com.cn/chanjing/gsnews/20130725/022216232701.shtml (accessed on 20 February 2022).

Rosier, Kevin. 2014. The Risks of China's Internet Companies on U.S. Stock Exchanges. Available online: https://www.uscc.gov/ research/risks-chinas-internet-companies-us-stock-exchanges-addendum-added-september-12-2014 (accessed on 15 February 2022).

Securities and Exchange Commission. 2014. Form-1 (Alibaba IPO Prospectus). May 6. Available online: https://www.sec.gov/ Archives/edgar/data/1577552/000119312514184994/d709111df1.htm (accessed on 7 September 2019).

Shi, Jinfeng. 2011. Di'sanfang Zhifu Paizhao Xijie Fupan: Yanghang Fahan Yaoqiu Baobei [Retrospecting Administrative Approval Details of Third Party Payment License: People's Bank of China Requested Document Filing]. Ershiyi Shiji Jingji Baodao. Reposted by Sina. June 22. Available online: http:/ / finance.sina.com.cn/chuangye/internet/20110622/100810029745.shtml (accessed on 24 September 2020).

Shi, Serena Y. 2013. Dragon's house of cards: Perils of investing in variable interest entities domiciled in the People's Republic of China and listed in the United States. Fordham International Law Journal 37: 1265.

Steinert, Timothy. 2021. Personal Profile. Linkedin. Available online: https://hk.linkedin.com/in/timsteinert (accessed on 1 September 2021).

Su, Longfei. 2014. Alibaba Rongzi Shi (Fundraising History of Alibaba). Xin Caifu. Quoted in "Alibaba Rongzishi, Cong Tianshilun, VC, PE dao 1000yi Meiyuan Shizhi de IPO (Fundraising History of Alibaba, from the Round of Angle Investment to VC, PE and the IPO That Worth 100 US\$ Billion)". June 17. Available online: http://www.valuetize.com/global/?p=1565 (accessed on 14 September 2020).

U.S.-China Economic and Security Review Commission. 2021. Chinese Companies Listed on Major U.S. Stock Exchanges. Available online: https:/ / www.uscc.gov/sites/default/files/2021-05/Chinese_Companies_on_US_Stock_Exchanges_5-2021.pdf (accessed on 15 February 2022).

Wang, Shanshan. 2011. Zhifubao Zhuanyi Zhenxiang [The Truth Behind Alipay's Transfer]. Caixin Xinshiji, June 4. Available online: https:/ / magazine.caixin.com/2011-06-04/100266286.html (accessed on 15 September 2020).

Wang, Shanshan, Ning Yu, Yongqiang Gu, and Tao Zhang. 2011a. Zhifubao 3.3yi Zhuanshou [The Transfer of Alipay at 330 million Yuan]. Caixin Xinshiji, May 16. Available online: https://magazine.caixin.com/2011-05-13/100258948.html (accessed on 25 September 2020). 
Wang, Shanshan, Yuzhe Zhang, Huawei Ling, Qiong Guo, Ziwu Wang, Fei Zheng, and Yanyan Fu. 2011b. Zhifubao Kaoyan [The test of Alipay]. Caixin Xinshiji, June 18. Available online: https:/ / magazine.caixin.com/2011-06-18/100270833.html (accessed on 22 November 2020).

Wangyi. 2011. Ma Yun Jiu Zhifubao Shijian Zhaokai Meiti Goutonghui Shilu [Records of The Press Conference Organized by Ma Yun Regarding the Alipay Incident]. June 15. Available online: https:/ /www.163.com/tech/article/76I66VUD000915BF.html (accessed on 25 September 2020).

World Trade Organization. n.d. DS413: China-Certain Measures Affecting Electronic Payment Services. Available online: https: //www.wto.org/english/tratop_e/dispu_e/cases_e/ds413_e.htm (accessed on 24 September 2020).

Xinhua. 2014. Alibaba Shangyan Hua'erjie 'Zhongguo Qiji' [Alibaba Shows a "Chinese Miracle" on Wall Street]. September 19. Available online: http:/ / www.xinhuanet.com/fortune/gsbd/86.htm/ (accessed on 21 July 2020).

Yang, Jing, and Lingling Wei. 2020. China's President Xi Jinping Personally Scuttled Jack Ma's Ant IPO. The Wall Street Journal, November 12. Available online: https:/ / www.wsj.com/articles/china-president-xi-jinping-halted-jack-ma-ant-ipo-11605203556 (accessed on 12 November 2020).

Yiu, Enoch. 2020. Hong Kong exchange, spurred by Alibaba, Xiaomi listings, proposes expansion of IPO reforms to attract more tech giants. South China Morning Post, January 31. Available online: https://www.scmp.com/business/banking-finance/article/3048 471/hong-kong-exchange-spurred-alibaba-xiaomi-listings (accessed on 22 September 2020).

Zhang, Chao. 2019. Alibaba IPO Wangshi (Alibaba's IPO Story). Touzhong Wang, November 19. Available online: https://www. chinaventure.com.cn/news/80-20191119-350285.html (accessed on 14 September 2020). 